\title{
Albanian Households Behavior towards the Investment Alternatives
}

\section{Summary}

The article presents issues related to the investment alternatives for the households and the opportunities offers especially to Albanian families by the financial market. The main part of this study consists in developing empirical models, which can explain the behavior of Albanian individuals to invest in a particular portfolio.

A survey was conducted consisting in 300 questionnaires. The research covered different cities in Albania, selected basiclly on their size and geographical location. The models are developed the Binar Models (models with discrete values), where the dependable variables are binars. Independable variables are category.

In the developed equations are reflected the main factors influencing the probability of undertaking by individuals investments with no risk or with risk.

\section{Introduction}

The way how individual investors may alocate their savings changes in parallel with the country financial system. Different studies in developed countries show a noticable difference of households" portfolios linked with changes in financial system, from a banking oriented system towards financial markets. So, studying the structure of households" portfolio is important for understanding changes, which have taken place in the financial system of that country.

We often think that a considerable number of people do not consider important investing. In addition to the lack of capital for investing, people mostly think, that they need to be professional for investment or need a support of personal financial consultants.

${ }^{*}$ Dr, Faculty of Economics, University of Tirana, Albania.

** Dr, Faculty of Economics, University of Tirana, Albania. 


\section{How households" portfolios are developed?}

Classic family investments consist in:

- „Almost cash" instruments. Despite the value of the wealth, everyone is interested in keeping some cash as available money. These instruments offer high liquidity. Upon planning the current expenses, the first classic way of the family investing is saving money on a bank account. Another possibility would be investing on the cash market in different low risk an short term of maturity cash instruments. The two typical instruments from this group are treasury bonds and deposit certificates.

- Investment in mutual funds. It is a great opportunity for family investments. They are the best way of diversifying a single invertment undertaken by individuals. Also, investments in Indeces Funds are wide spread today, which are passively managed as they follow the flow of a certain index. While we are talking more and more about globalization, today individuals face the challenge of wanting international investments and perhaps the best way to achieve this, is by investing in Mutual Funds.

- Investment in real estate. People invest in real estate for economic and noneconomic reasons. Among noneconomic reasons we would mention: most of investors want to be much involved in their investments, as they feel happy and proud of being owners of that real estate. The main reason for investing in real estate is economic: maximization of the rate of return after taxes. Real estate offers to investors one or twice higher returns than investments in common shares. Often, biggest families invest in living houses, not just in developing countries, but in developed ones too. This real estate consitutes the biggest portfolio value for these families.

- Investment in shares. From its genetic content, the share differs much from other investment alternatives. It is kind of investing in something tangible, which increases the value and size. In most cases the return from the shares made that portfolio goes beyond the return of all other types of investments.

- Investment in bonds. Most people investing in shares often do not understand the big role of having bonds in their portfolio. Bonds generate low financial risk, but also smaller rate of return than shares or real estates.

- Speculative investments. In general, investors who carefully manage their portfolios have no more than $15 \%$ of the portfolio in this type of investment, considering the high risk. Speculative investments include investments in: precious metals, collections, precious stones etc. Highest profits are usually gained from the short-term markets fluctuation. It should be consdiered that such investments count 3 to 4 times more loss than gain.

- Pensions plans. Experts calculate that pensioners which would like to have a comfortable life need about $70-80 \%$ of their current income for future exsisting. So, they must invest not only in public social insurance scheme, but also invest individually in pensions funds. The contribution paid for pension plan is deductable before taxes, so this investment is associated with important benefits: 
a. gives the opportunity of saving with the higher contribution,

b. tax reduction of the interests, dividends and capital profits from pensions funds affects the possibility of increased investment from accumulation.

\section{Investment opportunities for households in Albania}

Family investments compare with the investment opportunities. Situation in our developing country, with low income rate per capita, where the Stock Market has been established 10-11 years ago and almost ,not functioning" shows that investment opportunities are very limited.

The classic investment of the Albanian family consists in bank deposits. During the first year of political pluralism, individuals had deposited their savings mainly in Savings Bank, because the National Commercial Bank offered services only for enterprises. Money is deposited in banks as: current accounts, defined and undefined term deposits.

The level of deposits is considerably increased (see: table 1). In a period of seven years it was $233 \%$ growth rate for residents" deposits, as a result of increased GDP and role of banking system.

Despite of the fact that the number of financial instruments relevant to families is very small, the financial instruments offering by government (treasury bonds) is also one of the forms of cash saving. The interest rate of treasury bonds has always been higher than the deposits interest rate with this same maturity term, but this money asset has lower risk.

Government bonds were issued first time in 1991. In 2002, there were the first authentic government bonds issued with a maturity term of 2 years, followed by five year bonds issued in 2005. It may not be considered as an investment instrument, because there was almost no type of this investment mentioned.

There are many Joint-Stock-Companies in Albania, but none of them are registered at Tirana Stock-Market. Important for this study is known, that there are a considerable number of Joint-Stock-Companies (let's refer to transactions of buying and selling of shares in the year: for instance in 2006 there are 140 transactions, 1637755 shares). The fact of many Joint-Stock-Companies being in Albania and the number increasing means that there

Table 1. Ammount of residents deposits

\begin{tabular}{|c|c|c|c|c|c|c|c|c|}
\hline Year & $\mathbf{2 0 0 0}$ & $\mathbf{2 0 0 1}$ & $\mathbf{2 0 0 2}$ & $\mathbf{2 0 0 3}$ & $\mathbf{2 0 0 4}$ & $\mathbf{2 0 0 5}$ & $\mathbf{2 0 0 6}$ & $\mathbf{2 0 0 7}$ \\
\hline $\begin{array}{l}\text { Deposits of Residents } \\
\text { (mln ALL) }\end{array}$ & 182112 & 275224 & 285844 & 271620 & 369101 & 428347 & 511014 & 606216 \\
\hline
\end{tabular}

Source: Bank of Albania.

Table 2. Interest Rates of Deposits and Treasury Bonds

\begin{tabular}{|c|c|c|c|c|c|c|c|c|}
\hline Year & $\mathbf{2 0 0 1}$ & $\mathbf{2 0 0 2}$ & $\mathbf{2 0 0 3}$ & $\mathbf{2 0 0 4}$ & $\mathbf{2 0 0 5}$ & $\mathbf{2 0 0 6}$ & $\mathbf{2 0 0 7}$ & Sept. 2008 \\
\hline ALL Deposits interest (6 month) in \% & 7,40 & 8,90 & 7,07 & 5,41 & 4,77 & 4,64 & 5,50 & 5,81 \\
\hline Treasury Bond (6-M) interest rate in \% & 9,80 & 12,02 & 8,83 & 7,22 & 6,91 & 7,18 & 7,51 & 7,33 \\
\hline
\end{tabular}

Source: Bank of Albania. 
are opportunities in the market to invest in shares, even the liquidity of the share is not high.

It is not often clear the difference between investment in shares and opening a business. The main reason is that the most shareholders are very big (owning up to $98 \%$ of the company's shares), which means that management of the Joint-Stock-Companies is similar to the one of an individual business or partnership. After 1990s, Albanians were eager of starting business activity, something denied for so many years. So, the transition into trade market associated by such eagerness for private entrepreneurship, led in the creation of big number of private activities in different sectors, with the most important in services and construction.

Actually operate in Albania three private pensions" funds: GARANTSIG IPP, American Institute of Supplementary Private Pension of Albania and CAPITAL. Their activities are still at a low scale, counting 2621 clients with a total value contributed at 13,15 mln ALL. The lack of culture and experience for such investment schemes is one of the main factors, inhibiting the initiative for investing in these funds. Other factors are: small individual income level, some events like political unrest in 1997 (right after that of 1990), fall of pyramid schemes, big panic and fear of losing bank deposits (2002), which have left a ,taste" bitter at citizens and need time to be left behind. The high informality in Albania doesn't stimulate businesses to provide supplementary insurances for their employees as well.

As already known, the main characteristic of investments in real estates is in particular the protection against inflation. The possibility of collecting fixed incomes from real estate renting (for business activity, housing etc) is another advantage to be mentioned for this type of investment. Renting of real estate is characteristic especially for Tirana, where rents are higher compared with other cities. Construction sector in Albania has been most developed after the 1990s. The increasing needs for shelter drove and led to very fast development of this sector.

\section{The structure of the Albanian households" portfolio}

To add more value for this study and achieving accurate results, a survey consisting in 300 questionnaires was conducted. The questionnaire was designed simple: easy to understand and to fill out. The survey covered different cities in Albania: Tirana, Durres, Korca, Vlora, Elbasan, Lezha, Lac, Librazhd, Kukes, Saranda, Gjirokastra, Permet and Berat, selected based on size (large, small and mid size cities), geographical location, and the number of questionnaires for each city depended on respective population. The selection of individuals for the survey was random. The interviewed people were in different age (over 22 years old), different level of education and different social categories.

The questions in survey mainly consisted in, the way how the savings of Albanians are invested (even knowing, there are few alternatives), and the main reasons effecting their decision.

Based on the data collected from the survey, the weighing of the type of investments in the Albanian households" portfolio is shown in Figure 1. 
Figure 1. Investments in Albanian Households Portfolios

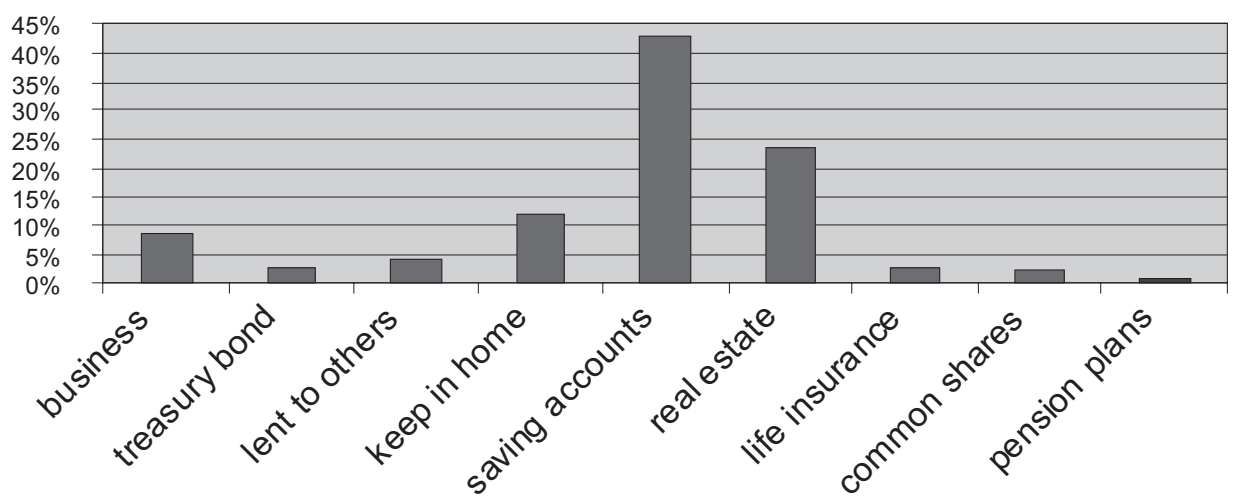

It is evident that the largest part of investment portfolios consists in bank deposits (saving accounts), making $42,6 \%$ of total investments. The second popular form of investment is real estates ( $23,7 \%$ of total investment), but not investment has the third place (we keep the money in our house-11,9\%). The people giving this answer had low incomes and so they kept the savings in house for covering immediate needs. Upon these savings achieved a considerable amount they intended to deposit in a bank, or to buy house equipment. Investments in business make only $9 \%$ of households.

The Albanian households have their financial portfolios. Referring to the survey, $26 \%$ of the interviewes has no savings, or some low amounts, almost non considerable. Meanwhile $74 \%$ of them have their own portfolio (even in some cases it consists just in one instrument). In this group of portfolios, dominates the non risk portfolio at $38 \%$ of cases. $33 \%$ of portfolios are a combination of non risk investments and real estates, $18 \%$ of portfolios are a combination of non risk investments and risk investments, and $11 \%$ of portfolios are a combination of non risk investments, risk investments and real estates. These kinds of households" portfolios are comparable with the households" portfolios in other countries. In Italy, for example, $75 \%$ of investment portfolios consist in non risk investments or on combination of non risk aseets and real estates. The advantage of residents in developed countries is that, they have the opportunity of choosing among a number of instruments for every kind of investment. Their financial incomes or their savings are higher, too.

\subsection{The reasons affecting Albanian households" investments}

Two main reasons forcing households to invest in saving accounts and treasury bonds:

- the low risk ( $40,5 \%$ of answers),

- the high liquidity (38,7\% of answers).

Meanwhile, there are considerable cases of answers, like: it doesn't take a lot of time; and little savings, so we deposit the money at the bank to accumulate them.

Investments in real estates consist mainly in: 
- residence for living $(74 \%)$,

- property for renting or reselling $(16 \%)$,

- land (4\%),

- holiday house (4\%).

Two main reasons forcing households to invest in real estate are: in $56,8 \%$ - the security (they are safer), and in 20,9\% - higher rates of return (high profit). There are considerable cases with answers, like: the necessity of meeting the needs for accommodation, and the satisfaction of owning.

Investment in business and in common shares is selected mainly, because it offers high rates of return. This kind of investment is stimulated by two main reasons:

- tradition of borrowing - financial support for friends,

- high return rates.

Investing in life insurance and pensions fund are at very low level (almost inconsiderable). Investing in first alternative is indirectly obligatory, as individuals have been forced by credit to buy real estate, or it has been a criterion when applying at embassies for visa. While at the second case, the pushing factor has been related to securing a supplementary pension, which means a safer future.

\subsection{Types of investment for different levels of income and age groups}

We thought of doing statistical analyses, based on frequencies for the existing dependence of type of investment and the category of incomes, which it belongs to as well as the same dependence from age groups the individual is part of.

As it appears in the Figure 2, individuals in the first category of income have no possibility of saving. Low own savings they may accumulate investing on assets with no risk, which offer high liquidity. The possibility of saving for the second category of income is also very low. People from this group of personal income invest mostly in non risk financial assets. Interested is the last group of people with personal income over 200.000 ALL. This group is very small, and their investment is also not too big, mainly making in riskly investment opportunities, such as own businesses.

In the Figure 3 we can see that investment process is especially realized by relatively young people. Their investment is based on non risk assets. At the early stage of

Figure 2. Investments by levels of incomes

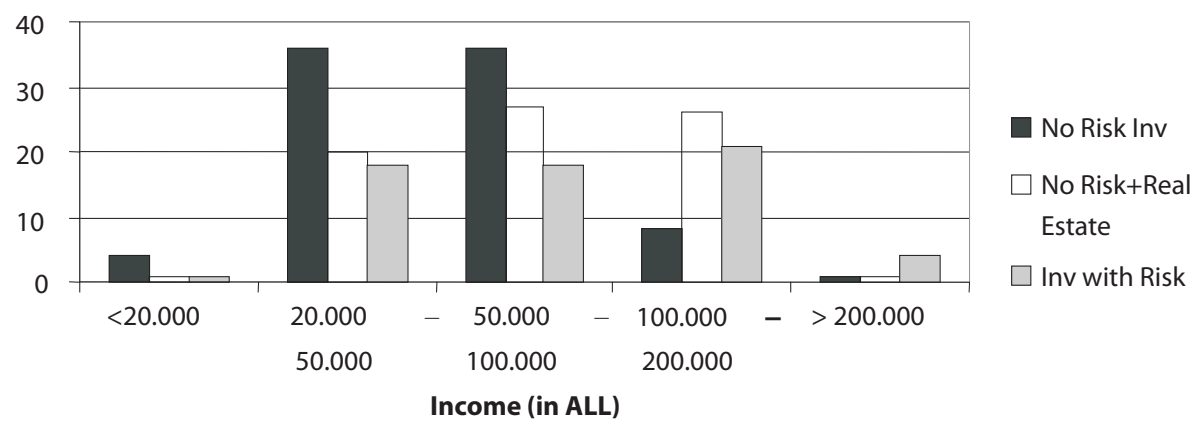


Figure 3. Investments by age groups

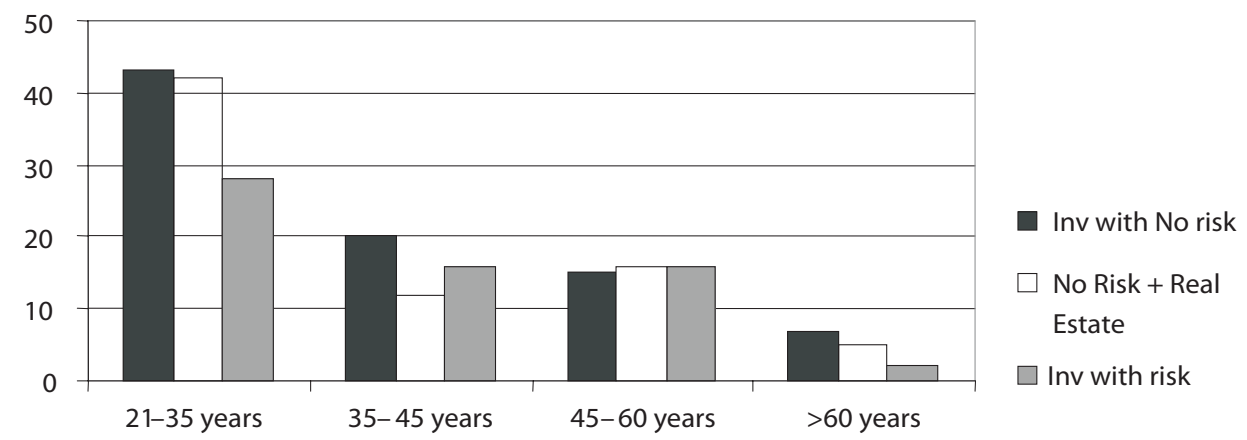

employment, individuals from this group of age have not only low salaries, but also little savings per person. The average age for investing and buying living house is $35-45$ years old.

Individuals of the age group 35-45 years old and 45-60 much or less behave similarly investing opportunities. For the group of 35-45, investments in real estate mainly consist in meeting the needs for shelter, while individuals closer to upper age of the group invest mainly in real estate for renting or reselling, as they already have met the needs for shelter. Individual of this age group besides taking on more risk they have more capital, so that the weigh of risky portfolio increases.

Individual of the group 45-60 have much or less the same probability of choosing the three types of investment. Certainly, that choosing depends on investor's decision to take on or not risk income, as well as from saved capital. Investments in real estates are mainly for houses for renting or reselling.

When analyzing the age group of over 60 -years, investments with no risk suddenly increase, which weigh most for this group. This age is characterized by a low level of risk tolerance and low income (they are mostly pensioners), which justifies their choice.

\section{Development of empiric models for defining individuals" behavior towards investing in a specific portfolio}

Having statistical datas from questionnaires and their analyses (depending on frequencies) we decided on developing an empirical model which tests the behavior of Albanian citizens" in choosing the type of investment. The model can show, which are the main factors defining the individuals" behavior on investing or not, and respectively shows the effect that these factors (categories) have on the probability of an individual part of that particular category, invest in a specific portfolio.

The models are binary type (model with discrete values), as the dependable variables are binary, which means to have values: 0 or 1 . Undependable variables are of the category type, so with discrete values (from 1 to $\mathrm{n}$ ), depending on sub-divisions of each category. 
The first model shows which the main factors are influencing on the probability that an individual only undertake investment without risk. Investors who had invested their savings only in treasury bonds and savings account we included in the group of investments without risk. From the analyses done, it results that among factors analyzed the income, age group, social category, life cycle, equation level, living location, planning, planning way, time of planning, only the category of ,age group" and ,life cycle” influence considerably in defining the behavior of individual for choosing this type of investment.

\begin{tabular}{|l|c|}
\hline \multicolumn{1}{|c|}{ Model parameters } & Value \\
\hline Hosmer and Lemeshow Test & 0,65 \\
\hline Classification table & 87,3 \\
\hline Nagelkerke R. Square & 0,10 \\
\hline
\end{tabular}

The first empirical model is characterized by such parameters:

1. Hosmer and Lemeshow Test. It is a parameter measuring the importance of the model and, in our case, the level of its importance is $65 \%$. This value should be smaller than 0,15 , so this model is important for explaining the behavior of Albanians linked with the probability of undertaking only investment without risk.

2. The parameter of Clasification Table, which shows the accuracy of the model and the value 87,3 shows that the model explains the behavior of Albanians with an high accuracy $-87,3 \%$.

3. R. Square measures - how explainable are case with the model, and in our case it is a satisfying parameter, as the maximum that value may reach is 0,33 .

Equation 1.

$P($ Investments with no risk $)=$

$=($ Constant $)+\sum_{i=1}^{4} \alpha_{i}^{*}(\text { Age })_{i}+\sum_{i=1}^{4} \gamma_{i}(\text { life cycle })_{i}+\varepsilon_{t}$

where: $\varepsilon$ is the error of the model coming from variables that can't be observed and estimated.

$P($ Investments with no risk $)=$

$=(0,23)+\left(\begin{array}{ll}\alpha_{1}^{*} & \text { age } \\ \alpha_{2} * & \text { age } \\ \alpha_{3} * & \text { age }_{3} \\ \alpha_{4} * & \text { age }_{4}\end{array}\right)+\left(\begin{array}{l}\gamma_{1} * \text { life cycle } \\ \gamma_{2} * \text { life } \text { cycle } \\ 2 \\ \gamma_{3} * \text { life cycle } \\ \gamma_{4} * \text { life cycle }\end{array}\right)+\varepsilon_{t}$ 
$P($ Investments with no risk $)=$

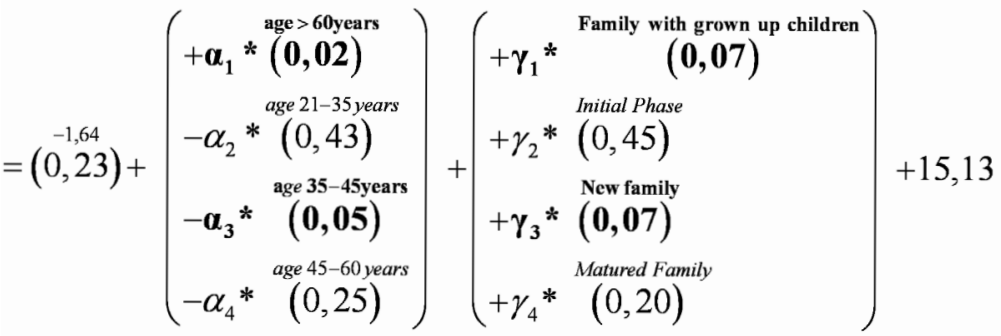

So, as it may be seen at the function above, only the category ,age group” and ,life cycle" influence considerably in defining the individuals" behavior in choosing this type of investment.

From ,age groups" category as it also appears at the importance level, the probability to invest only in no risk instruments, is influenced by the behavior of age group beyond 60 years (with importance level 0,02, so 98\%), and age group 35-45 (with importance level 0,05 , so probability $95 \%$ ). Individuals of the age group of over 60 years and that of $35-$ 45 , reflect a specific behavior towards investing in no risk instruments (or with very low risk). For defining type of behavior we refer to signs (positive or negative) of coefficient $\alpha_{i}$, for the ,age group" category.

For the ,age group" of over 60 years, the positive sign of $\alpha_{1}$, shows that probability of investing in instruments with no risk is high. The coefficient $\alpha$ itself shows an exponential function. The positive value means an indicator more than 1 , while the negative value means an indicator less than 1 . This is the reason we come in the conclusion that the probability for investing in non risk instruments for this age is high. This age group is characterized in general by low income, as well undertaking low risk initiatives. The second one influence to choosing no risk investments, while the first one in low possibilities for investing.

Otherwise, the negative sign of $\alpha_{3}$, means that the age group 35-45 years old, has low probability for investing in low risk instruments. Individuals of this age groups, with already of 12 years experience, secure higher income and have accumulated a certain capital. This capital, the initiative for taking on the risk, the knowledge and the gained experience, the increase of living standard and higher expectations, offers to these individuals" investment opportunities in different instruments, and not just in no risk instruments.

The second model, defines which are the main factors influencing the probability of an individual to undertake risk investments. In the group of risk investments, we included the households who had certainly invested in business or shares, despite of credits to third parties, real estate, saving accounts, treasury bonds, etc, in their portfolios. From the analyses done, comes out that among the factors tested - incomes, age group, social categories, life cycle, education level, living location, planning, the way of planning, period of planning - just the category of ,income” and „the way of planning”, considerably influence in the defining the behavior of individuals in choosing this type of investment. 


\begin{tabular}{|l|c|}
\hline \multicolumn{1}{|c|}{ Parameters of Model } & Value \\
\hline Hosmer and Lemeshow Test & 0,36 \\
\hline Classification table & 80,2 \\
\hline Nagelkerke R. Square & 0,12 \\
\hline
\end{tabular}

The second empirical model is characterized by these parameters:

1. Hosmer and Lemeshow Test, indicates that the importance level of the model is $36 \%$. For the reason being that this value should not be less than 0,15 , we conclude that this model is important, so it explains the Albanians behavior linked with the probability to take on risk investments.

2. The value 80,2 of the Classification Table parameter shows that the model explains the Albanians behavior with high accuracy $80,2 \%$.

3. The value of R. Square parameter, linked with explainableness of the model is considerable, as the maximum this value may get is 0,33 , and our value 0,12 shows that the model explains $38 \%$ of the cases.

Equation 2.

$P($ Investments with risk $)=$

$=($ Constant $)+\sum_{i=1}^{4} \alpha_{i}^{*}(\text { Period of planning })_{i}+\sum_{i=1}^{5} \gamma_{i}(\text { Incomes })_{i}+\varepsilon_{t}$

$P($ Investments with risk $)=$

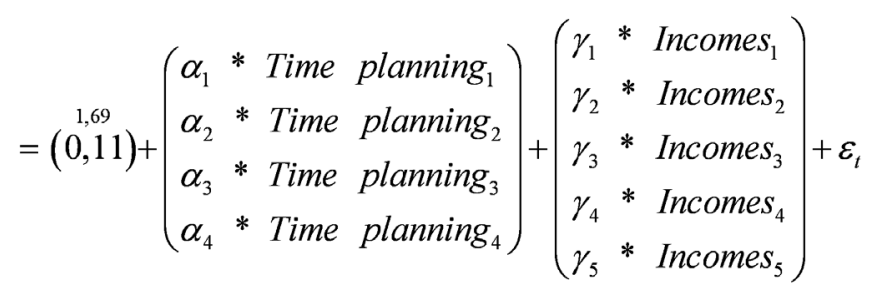

$P($ Investment with risk $)=$

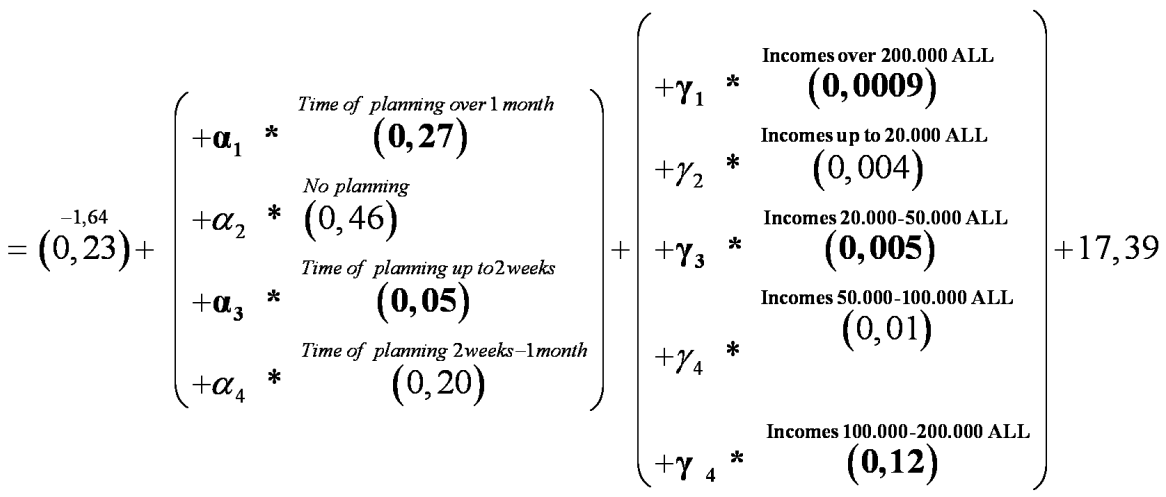


From the category „time of planning”, as it can be noticed from the level of importance, the probability for investing in riskly instruments is influenced from the time of planningup to 2 weeks. Especially the individuals preparing two weeks financial plan (with level of importance 0,05 ) with a $95 \%$ probability, demonstrate a specific behavior taking on the risk while investing. We refer to the sign of $\alpha_{3}$ coefficient for this category, to define the way of behavior. The positive sign of $\alpha_{3}$, demonstrate that the probability for the investor of this category to take on risk is high. As we are talking about riskly investments by generally referring to business activities, doing weekly or bi-weekly plans (purchasing expenses, income from sales, pay back of short term debts, etc) we think that they have developed a culture of financial planning for these individuals. So, they also plan family finances for the same period. The idea gets reinforced, considering that the family and family business finances converge (the source of income has no importance, as they do common purchases for home and business as well).

When referring to the ,income" category, it is clear that in individual behavior for undertaking riskly investments, all categories influence. This is supported by very high importance level for any of them. So, the I, II, and IV categories of incomes have 0,01 level of importance, the III category has 0,05 level of importance, while the V category has no much importance. Even though this level of importance we think that it is result of limited number of interviewers for this category, because if referring to the analyze of frequencies above, this category is characterized by high probability of taking on risk. The positive

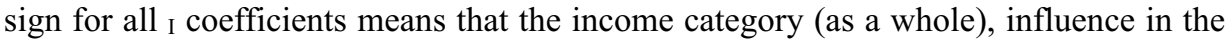
individual behavior for taking on the risk (investments on riskly portfolio), thus on the probability of taking on the riskly investments.

For a more accurate analyze, we refer to the $\operatorname{Exp}(\beta)$ indicator which shows the marginal effect. This indicator increases from lower income categories to higher ones, which shows that the level of income is positively correlated with the probability of investing in riskly instruments, thus such probability increases for higher income. For instance, the probability for an individual to undertake riskly investments increases with $24 \%$ when an individual moves from the category of income 100 000-200 000 ALL, to the category of income over 200000 ALL.

\begin{tabular}{|c|c|c|c|}
\hline Category of Income & Sign o $\boldsymbol{\gamma}_{\boldsymbol{i}}$ & Level of Importance & $\operatorname{Exp}(\boldsymbol{\beta})$ \\
\hline$<20000 \mathrm{ALL}$ & + & 0,003 & 0,02 \\
\hline $20000-50000 \mathrm{ALL}$ & + & 0,005 & 0,07 \\
\hline $50000-100000 \mathrm{ALL}$ & + & 0,009 & 0,09 \\
\hline $100000-200000 \mathrm{ALL}$ & + & 0,12 & 0,24 \\
\hline$>200000 \mathrm{ALL}$ & + & 0,0008 & \\
\hline
\end{tabular}

In the same way, we analyze the main factors which would influence the probability of an individual to invest in a portfolio composed of non risk instruments and real estates, but their effect didn't result important, so we couldn't get at the point of developing a similar empirical model for this kind of portfolio. So the only analyses we did (despite of the frequencies above) was by calculating the correlation coefficient. 
Table 3. Correlation coefficients for portfolios made up from Investments with No Risk and Real Estate

\begin{tabular}{|c|c|c|c|c|c|c|c|c|c|c|}
\hline \multicolumn{2}{|c|}{} & Age & $\begin{array}{c}\text { Civil } \\
\text { Status }\end{array}$ & $\begin{array}{c}\text { Way of } \\
\text { plan- } \\
\text { ning }\end{array}$ & $\begin{array}{c}\text { Living } \\
\text { Place }\end{array}$ & $\begin{array}{c}\text { Time of } \\
\text { Plann- } \\
\text { ing }\end{array}$ & Incomes & $\begin{array}{c}\text { Educa- } \\
\text { tion } \\
\text { Exp. }\end{array}$ & $\begin{array}{c}\text { Educa- } \\
\text { tion }\end{array}$ & $\begin{array}{c}\text { Life } \\
\text { Cycle }\end{array}$ \\
\hline $\begin{array}{c}\text { Inv. With no risk } \\
\text { \& real estate }\end{array}$ & $\begin{array}{c}\text { Pearson } \\
\text { Correlation }\end{array}$ &,- 025 &, $120\left(^{*}\right)$ &,- 004 &,- 100 &, 017 &, $242\left(^{* *}\right)$ &, 028 &, 091 &, 030 \\
\hline & Importance &, 666 &, 037 &, 940 &, 084 &, 772 &, 000 &, 685 &, 117 &, 599 \\
\hline
\end{tabular}

* Correlation is important in 0,01 level.

** Correlation is important in 0,05 level.

As it is shown in the table 3, the probability for investing in such kind of portfolios, is positively correlated (with high level of importance) with the category of incomes, and with social categories as well. So, the individual level of incomes substantially determines (with 98\% probability) their behavior for investing in non risk instruments and real estates. Also, the social category of an individual determines (with $95 \%$ probability) behavior for undertaking such kind of investments.

\section{Conclusions}

The Albanian market offers few investing opportunities for households. There is a lack of instruments quoted on the financial market, and in particular mutual funds, which are the best opportunity of households" investment, do not functioning. The state should find a rapid solution for increasing the role of stock market in Albania. This means increased investing opportunities for Albanians. Albanian savings are really low, but in this situation the possibility for increasing them is low.

While aspiring integration into Euro-Atlantic alliances, and exposed to the globalisation process, the financial system in the country is expected to change, which it would mean change into the household portofolio content.

The Albanian household investments consist in bank deposits, which make $42,6 \%$ of total investments, and real estates with $23,7 \%$. From the survey, $26 \%$ of the interviewes have either no savings or have little almost inconsiderable.

While, $74 \%$ of the interviewes have a specific portfolio (even it may consist of a single instrument). Among the developed portfolios, it is the one with no risk dominating at $38 \%$, while $33 \%$ of the portfolios are a combination of investment without risk and real estates, $18 \%$ are a combination investment without and with risk (business, shares), and 11\% combination of investment without risk, investment with risk and real estates.

The first empirical model shows that the ,age group" and „life cycle” categories influence on an important level of individuals" investment behavior and choosing only the investment without risk.

The second model determines that the ,income” and ,period of planning” categories influence importantly on individuals" behavior and choosing investments with risk. The indicator $\operatorname{Exp}(\beta)$ of marginal effect, which increases from lower income categories to higher 
ones, shows that the level of income is positively correlated with the probability of investing in riskly instruments, and probability increases for higher income.

\section{References}

Brumbulli S., Cfarë të bëj me kursimet?, 1997.

Christelis D., Jappelli T., Padula M., Cognitive Abilities and Portfolio Choice, 1999.

Crone T., Voith, R., Risk and return within the single family housing market, 1997.

Forsfalt T., The effect of risk aversion and the age of investments in New Firms, 1999.

Garman E.T., Forgue R.E., Personal Finance, $8^{\text {th }}$ Ed., Houghton Mifflin Company, Boston-New York 2005.

Ho K., Robinson Ch., Personal Financial Planning, ${ }^{\text {rd }}$ Ed., Canada 2002.

INSTAT (2004), Shqipëria në shifra.

Meka E., Bursa e Tiranës si Treg Kapitalesh në Shqipëri, 2007.

\section{Zachowania inwestycyjne gospodarstw domowych w Albanii}

\section{Streszczenie}

Artykut prezentuje możliwości i zachowania inwestycyjne gospodarstw domowych w Albanii. Jego główna część poświęcona jest wynikom badania opartego na modelach empirycznych, wykazujacych podstawowe determinanty indywidualnych zachowań inwestycyjnych. Badania zostaty oparte na danych pochodzacych z przeprowadzonego na próbie 300 respondentów kwestionariusza wywiadu. Wyniki badań wykazuja silna korelacje między poziomem akceptowanego ryzyka i zachowaniem inwestycyjnym albańskich gospodarstw domowych. 